\title{
Cystoidosoma hermaphroditus sp. n., the first representative of the quill mite family Ascouracaridae (Acari: Astigmata: Pterolichoidea) from an owl (Aves: Strigiformes)
}

\author{
Fabio Akashi Hernandes ${ }^{1}$ and Barry M. OConnor ${ }^{2}$ \\ ${ }^{1}$ Departamento de Zoologia, Universidade Estadual Paulista, Rio Claro, São Paulo, Brazil; \\ ${ }^{2}$ Department of Ecology and Evolutionary Biology, Museum of Zoology, University of Michigan, Ann Arbor, Michigan, USA
}

\begin{abstract}
The mite family Ascouracaridae Gaud et Atyeo, 1976 contains large-sized mites (mostly $>1 \mathrm{~mm}$ ) which live inside the quills of birds of several orders. To date, no representative of this family has been found associated with the order Strigiformes (owls). In this paper, a new species of this family, Cystoidosoma hermaphroditus sp. n., is described from the tropical screech owl, Megascops choliba (Vieillot) (Aves: Strigiformes) from Brazil. This species is unique in having an external spermaduct, a primary duct and a rudimentary bursa copulatrix present in males. This is the first astigmatan feather mite described from the order Strigiformes in this country. A key to adults of the genus Cystoidosoma Gaud et Atyeo, 1976 of the world is presented.
\end{abstract}

Keywords: feather mites, Megascops choliba, hermaphroditism, taxonomy, systematics, identification key

The family Ascouracaridae Gaud et Atyeo, 1976 (Acari: Astigmata) contains large-sized mites $(>1 \mathrm{~mm})$ that inhabit the quills of several bird orders (Gaud and Atyeo 1996, Mironov and Fain 2003). This taxon was first proposed as a subfamily of the Syringobiidae Trouessart, 1897 by Gaud and Atyeo (1976) and later was elevated to family by Gaud et al. (1989). Twenty-two species in seven genera have been described (Gaud and Kolebinova 1973, Gaud and Atyeo 1976, d'Souza and Jagannath 1982, Dabert and Ehrnsberger 1992, 1995, Proctor 1999, Mironov and Fain 2003). The larva is the dispersal stage and is strongly heteromorphic in relation to subsequent stages, being elongate and highly sclerotised, in contrast to the bulky and relatively poorly sclerotised body - especially the hysterosoma - of adults (Dabert and Ehrnsberger 1992, Proctor 1999).

Mironov and Fain (2003) summarised the known host associations for species of this family, reporting associations with the avian orders: Accipitriformes, Apodiformes, Caprimulgiformes, Galliformes, Passeriformes, Piciformes and Psittaciformes. The order Strigiformes (owls) has a poor record of mites in Brazil, with only Ornithonyssus bursa (Berlese, 1888) (Mesostigmata: Macronyssidae) having been reported from Megascops choliba (Vieillot) (Mascarenhas et al. 2009). As for the feather mites (Astigmata), only three ascouracarid species have been reported from Brazil (Valim et al. 2011): Ascouracarus chordeili Mironov et Fain, 2003 from Chordeiles rupestris (Spix) (Caprimulgiformes), Cystoidosoma psittacivorae Dabert et Ehrnsberger, 1992 from Aratinga aurea (Gmelin), and Cystoidosoma aratingae Mironov et Fain, 2003 from Aratinga jandaya (Gmelin) (Psittaciformes).

In the present paper a new species of the genus Cystoidosoma Gaud et Atyeo, 1976 is described from M. choliba (Strigiformes: Strigidae) in Brazil. This is the first representative of the family Ascouracaridae described from the avian order Strigiformes and also the first astigmatid mite described from this bird order in Brazil. A key to adults of the genus Cystoidosoma of the world is presented.

\section{MATERIALS AND METHODS}

Mites were collected from a tropical screech owl (Fig. 1A) captured in a mist-net. A few wing feathers were removed and stored in ziploc plastic bags, and the owl was released back into the wild. Mites were cleared in 30\% lactic acid and mounted in Hoyer's medium (Krantz and Walter 2009). Measurements and descriptive method follow recent publications on the taxonomy of Ascouracaridae - see Dabert and Ehrnsberger (1992), Mironov and Fain (2003). The chaetotaxy of idiosoma and legs follows that of Griffiths et al. (1990) and Atyeo and Gaud (1966), respectivelly.

Address for correspondence: F.A. Hernandes, Departamento de Zoologia, Universidade Estadual Paulista, Rio Claro, São Paulo, Brazil 13506-900. Phone: +5519-35264296; Fax: +5519-35264300; E-mail: abakashi@gmail.com

ZooBank number for article: urn:1sid:zoobank.org:pub:7FF1DBC8-028F-4780-9469-5BAE99F8BFE8 


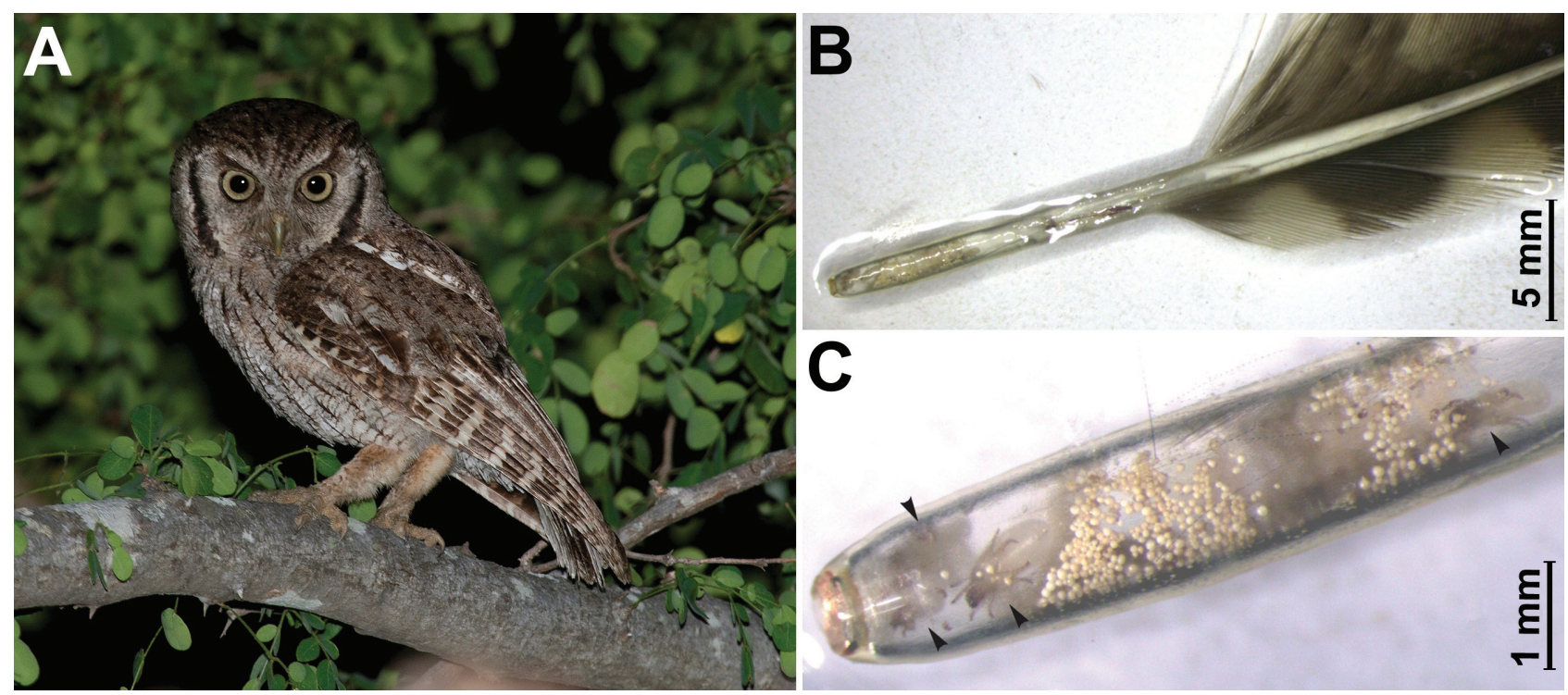

Fig. 1. A - Tropical screech owl, Megascops choliba (Vieillot); B - detail of wing feather; $\mathbf{C}$ - quill containing Cystoidosoma hermaphroditus sp. n. inside (arrows) (photo of M. choliba by Arthur Macarrão).

\section{RESULTS}

Superfamily Pterolichoidea Trouessart et Mégnin, 1884

Family Ascouracaridae Gaud et Atyeo, 1976

\section{Genus Cystoidosoma Gaud et Atyeo, 1976}

Type species: Cystoidosoma labidostoma Gaud et Atyeo, 1976, by original designation.

Species of the genus Cystoidosoma are characterised by lacking trochanteral setae on legs III, seta $k T$ present on tibia IV and dorsal setae $c 1$ shorter than the gnathosoma (Gaud and Atyeo 1996). The genus currently includes six species associated with the Psittaciformes, Piciformes and Accipitriformes (Gaud and Atyeo 1976, Dabert and Ehrnsberger 1992, Mironov and Fain 2003).

\section{Cystoidosoma hermaphroditus sp. n.}

Figs. 2-6

ZooBank number for species:

urn:1sid:zoobank.org:act:3214D00D-D9BA-

40EB-BD76-738D82D1E136

Description. Male (holotype) (Figs. 2, 3, 6B,D) (measurements of holotype followed by range for three paratypes in parentheses). Idiosoma length and width 1106 $\times 582(898-1003 \times 540-545)$. Subcapitulum length and width $164 \times 172(161-172 \times 163-168)$. Prodorsal shield length along midline 245 (242-251), width at base 377 (363-382). Seta vi 80 (74-83) in length, their bases coalescent, setae se 346 (357-376) in length, distance se-se 222 (200-226), setae si 130 (107-120) in length, distance $s i-s i$ 153 (136-160). Humeral shields present ventrally, bearing setae $c p$ and $c 3$. Setae $p s 1, h 2, h 3$ inserted on soft tegument, without surrounding sclerotisation. Cupules ia, im and ip present dorsally, cupules ih present ventrally flank- ing posterior part of anal opening. Gland opening $g l$ situated dorsally midway between bases of setae $d 2$ and $e 2$. Male unique in possessing external spermaduct similar to that of female, as short cone 17 (14-15) in length, situated dorsally between bases of setae $e l$ and $h 1$. Leading from opening to rudimentary bursa copulatrix (or spermatheca) similar to that of female but lacking sclerotised termini of ducts leading to ovaries in female. Length of dorsal setae: c1 80 (60-85), c2 104 (90-106), c3 89 (91-108), cp 354 (328-364), d1 36 (38-47), d2 89 (70-91), el 46 (43-46), e2 86 (84-94), f2 81 (59-76), h1 28 (36), h2 444 (386-430), h3 440 (378-486), ps 1458 (412-421), ps 90 (87-106), ps3 44 (41-51).

Anterior coxal apodemes I united as Y with short sternum, sclerotised coxal fields I with incision toward setae $1 a$. Genital arch horseshoe-shaped bearing pregenital sclerites with setae $g$ and genital papillae. Setae $3 b$ inserted on anterior coxal apodemes III, setae $4 a$ inserted on soft tegument posterolateral to bases of genital arch. Leg segments without spurs or apophyses. Distal tarsal seta $s$ lanceolate and enlarged, abruptly bent on anterior legs (Fig. 3B,D).

Female (measurements of four paratypes in parentheses) (Figs. 4, 5, 6A,C). Idiosoma length and width 997-1 $154 \times 520-629$. Subcapitulum length and width 164-172 × 164-173. Prodorsal shield length along midline 239-267, width at base 349-399. Seta vi 72-76 in length, their bases coalescent, setae se 354-374 in length, distance se-se 225-236, setae si 106-138 in length, distance si-si 154-168. Prodorsal and hysteronotal areas as in male. External spermaduct as short cone 12-16 in length, situated dorsally between bases of setae $e l$ and $h 1$. Spermathecal duct leading to sac-like spermatheca with sclerotised openings to ovarian ducts at base. Length of dorsal setae: c1 73-88, c2 92-129, c3 74-92, cp 322-391, d1 34-40, d2 72-87, el 26-45, e2 68-73, f2 55-66, h1 11-15, h2 303-413, h3 392-473, ps 1 298-360, ps 2 59-77, ps3 34-54. 


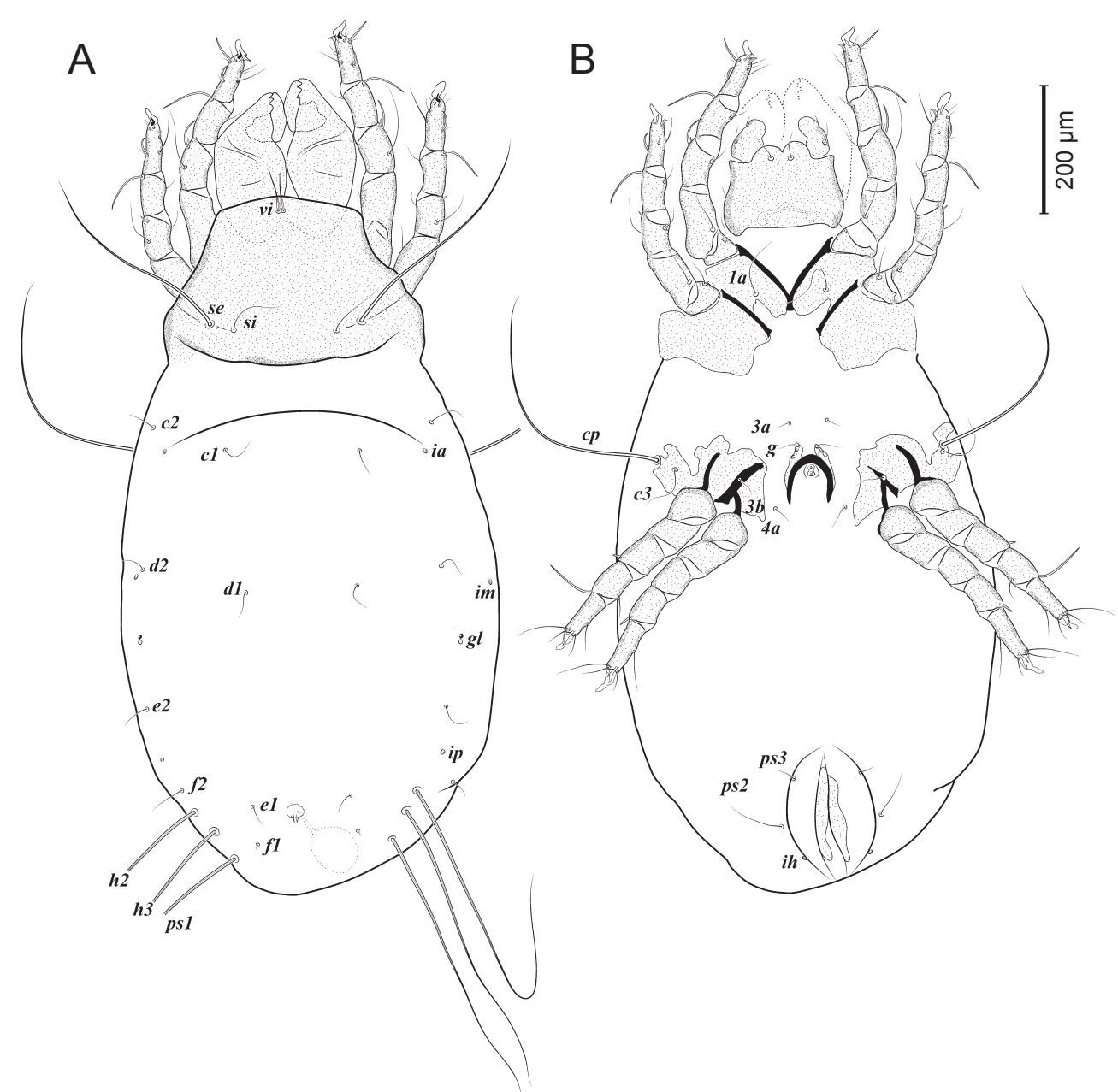

Fig. 2. Cystoidosoma hermaphroditus sp. n. from Megascops choliba (Vieillot), male habitus. A - dorsal view; B - ventral view.

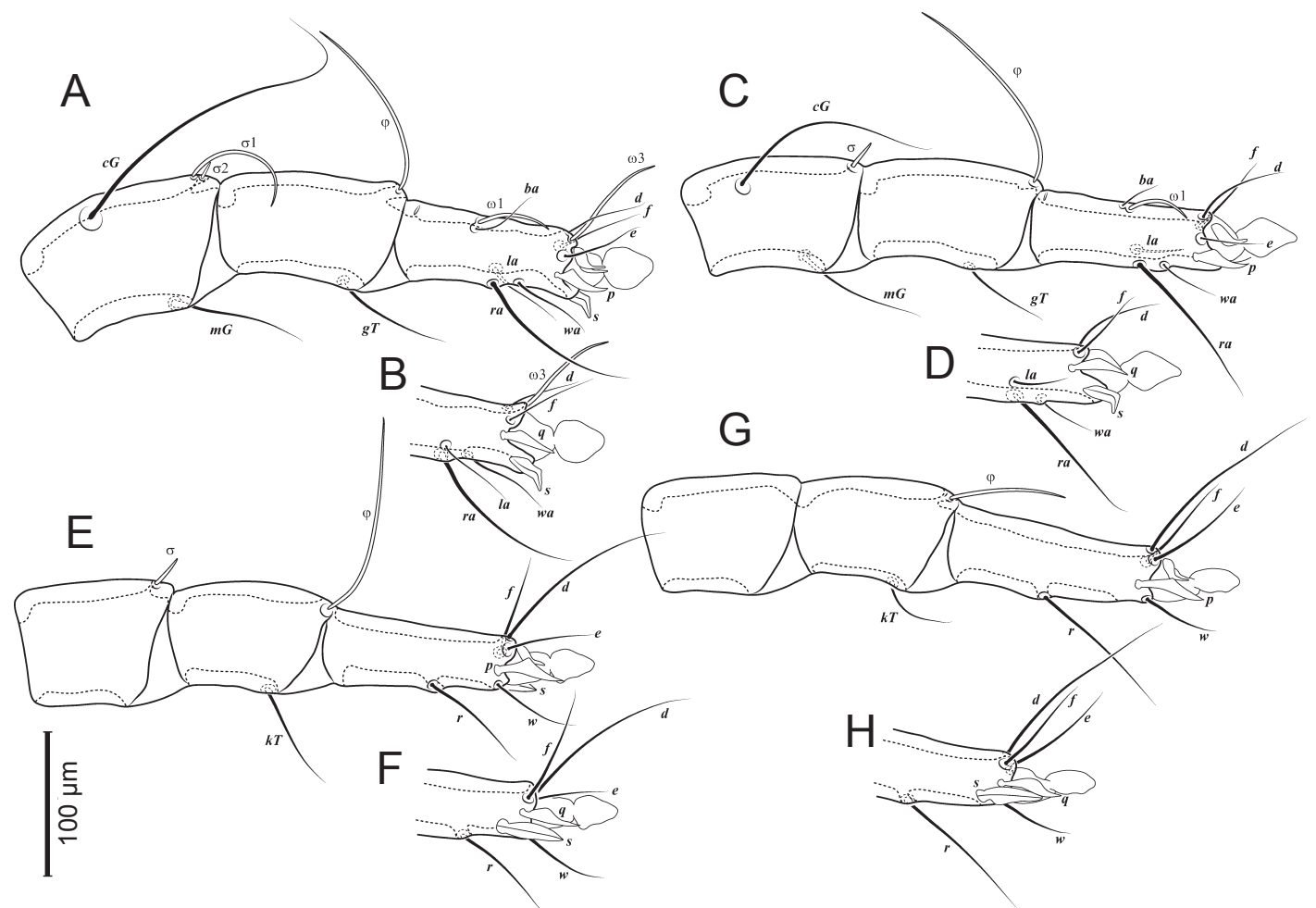

Fig. 3. Cystoidosoma hermaphroditus sp. n. from Megascops choliba (Vieillot), genua, tibiae and tarsus of male. A, B - leg I; C, D - leg II; E, F - leg III; G, H - leg IV (A, C, E, G - dorsal view; B, D, F, H - ventral view). 


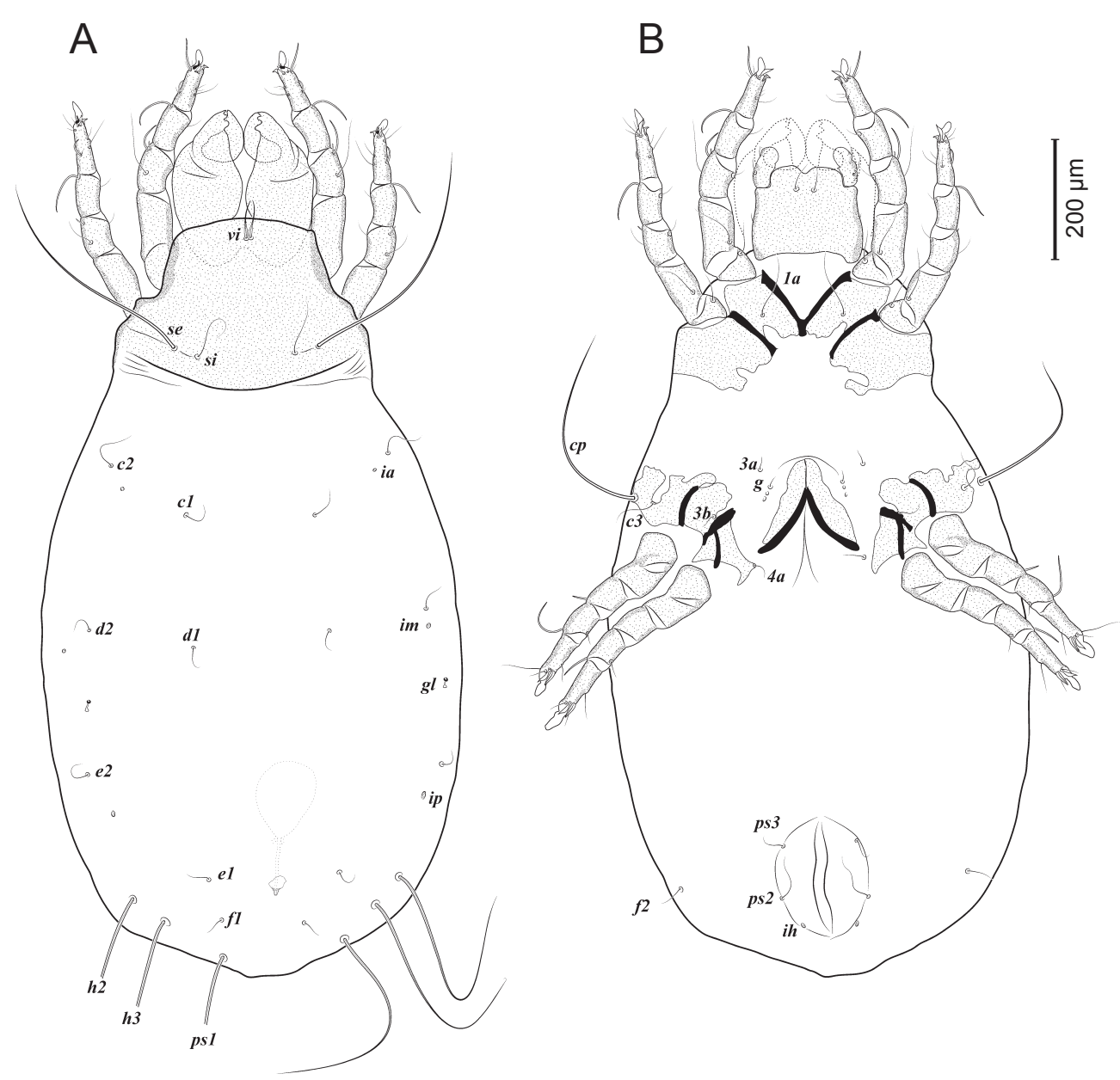

Fig. 4. Cystoidosoma hermaphroditus sp. n. from Megascops choliba (Vieillot), female habitus. A - dorsal view; B - ventral view.

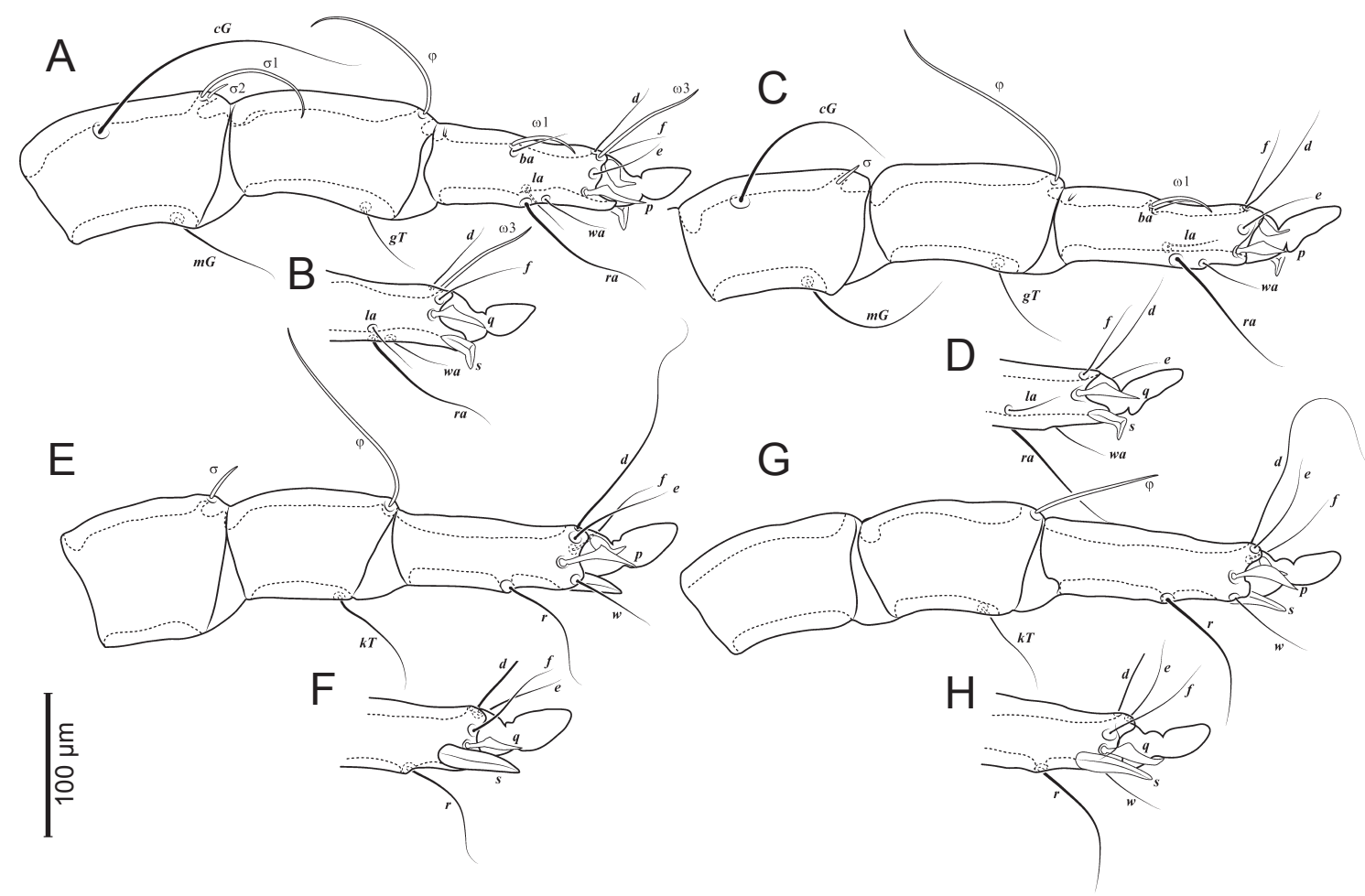

Fig. 5. Cystoidosoma hermaphroditus sp. n. from Megascops choliba (Vieillot), genua, tibiae and tarsus of female. A, B - leg I; C, D - leg II; E, F - leg III; G, H - leg IV (A, C, E, G - dorsal view; B, D, F, H - ventral view). 


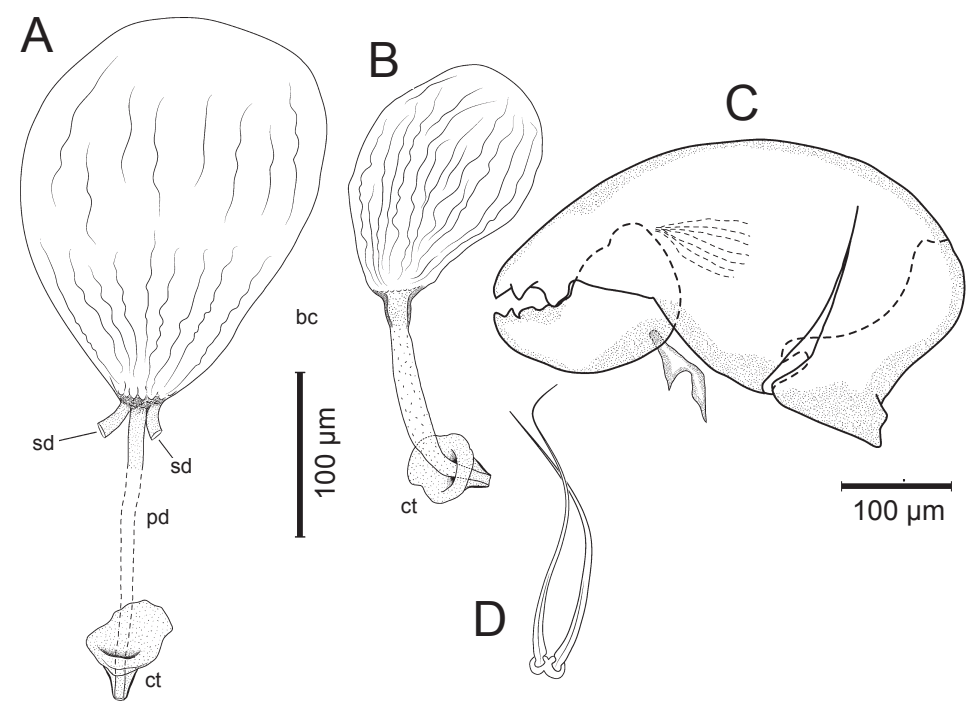

Fig. 6. Cystoidosoma hermaphroditus sp. n. from Megascops choliba (Vieillot). A - copulatory tube (ct) of female; B - copulatory tube of male; C - lateral view of female chelicera; D - prodorsal setae vi of male. Abbreviations: bc - bursa copulatrix; pd - primary duct; sd - secondary ducts.

Ventral surface as in male, except for differences in genital area (Fig. 4). Legs as in male (Fig. 5).

Type material: Holotype male (DZUnespRC-2721), 3 male and 7 female paratypes ex Megascops choliba (Vieillot) (Strigiformes: Strigidae), 2249'52"S; 47²6'08"W, Santa Bárbara d'Oeste, São Paulo State, Brazil, 2 March 2013, collected by Fabio A.F. Jacomassa. Holotype and 6 paratypes deposited in DZUnesp-RC - Collection of Acari of Department of Zoology of the Universidade Estadual Paulista, Rio Claro, São Paulo, Brazil; 2 male and 2 female paratypes in the University of Michigan Museum of Zoology, Ann Arbor, Michigan, USA.

Etymology: The specific name is a noun in apposition and refers to the character in Greek mythology, Hermaphroditos (Latin - Hermaphroditus), offspring of Hermes and Aphrodite, who was classically depicted as a male with some female sexual characteristics.

Differential diagnosis. Cystoidosoma hermaphroditus sp. n. resembles C. centuri Dabert et Ehrnsberger, 1992 in having setae $c 1$ short (not reaching prodorsal shield), longitudinal sclerites absent near setae $d 2$, bases of terminal setae $(h 2, h 3$, and $p s 1)$ not supported by sclerotisations, and scapular setae se about five times longer than si. The new species is clearly different in having an external copulatory tube and rudimentary spermatheca present in males.

Key to species of Cystoidosoma Gaud et Atyeo, 1976 of the world (adults)

1 Seta $c 1$ long, reaching prodorsal shield. 2

- Seta $c 1$ short, not reaching prodorsal shield.

2 Humeral shields not reaching setae $c 2$, coxal fields I separated from each other.

C. aratingae Mironov et Fain, 2003

- Humeral shields reaching setae $c 2$, coxal fields I fused.......... C. psittacivora Dabert et Ehrnsberger,1992
3 Seta se only sligthly longer than si.... C. labidostomma Gaud et Atyeo, 1976

- Setae se at least three times longer than si. 4

4 Longitudinal sclerites present near setae $d 2$. C. sacculipyga Dabert et Ehrnsberger, 1992

- Longitudinal sclerites absent near setae $d 2 \ldots \ldots \ldots \ldots . . . . .5$

5 Bases of setae $h 2, h 3$ and $p s 1$ situated on weakly sclerotised band

C. myiopsittae Mironov et Fain, 2003

- Bases of setae h2, h3 and ps 1 situated on soft tegument.

6 External copulatory tube present in females only; caudal setae $p s 1, h 2$ and $h 3$ transversely arranged.

C. centuri Dabert et Ehrnsberger 1992

- External copulatory tube present in both sexes; caudal setae $p s 1, h 2$ and $h 3$ obliquely arranged. C. hermaproditus sp. n.

\section{DISCUSSION}

Cystoidosoma hermaphroditus sp. $\mathrm{n}$. is the first feather mite (Astigmata: Psoroptidia) described from an owl in Brazil (see Valim et al. 2011). It is also the first record of the family Ascouracaridae associated with owls (Strigiformes) in the world. Other quill mites (Prostigmata: Syringophilidae), however, have been found on owls, including the three species of the genus Bubophilus Philips et Norton, 1978: B. ascalaphus Philips et Norton, 1978, B. asiobius Skoracki et Bochkov, 2002, and B. aluconis Natress et Skoracki, 2009, associated with Bubo virginianus (Gmelin), Asio otus (Linnaeus), and Strix aluco Linnaeus, respectively (Philips and Norton 1978, Skoracki and Bochkov 2002, Natress and Skoracki 2009). In the 
Ascouracaridae, it is typical for a single male and female to inhabit a single feather (OConnor 2009), but 11 adults were found inhabiting the same feather quill in the present study (Fig. 1 B,C).

In female astigmatans, the primary spermathecal duct (or inseminatory canal of Witalinski et al. 1990) sometimes extends outside the opisthosomal margins, forming an external copulatory tube, or external spermaduct (Walter and Proctor 2013), that leads to the bursa copulatrix (receptaculum seminis of Witalinski et al. 1990) (Fig. 6A) via the primary duct. The external tubes occur in females of many families including Pterolichoidea (Ascouracaridae, Caudiferidae, Crypturoptidae, Eustathiidae, Freyanidae, Pterolichidae, Thoracosathesidae), Analgoidea (Trouessartiidae), Glycyphagoidea (Echimyopodidae, Glycyphagidae, Rosensteiniidae) and Canestrinioidea (Canestriniidae). It is a remarkable and surprising fact of the present study that, males were also found to possess an external conelike spermaduct, an inseminatory canal and a rudimentary bursa copulatrix (Fig. 6B), much similar to those of females. This condition has not been previously reported in mite groups where sperm is introduced into the female reproductive system via a secondary opening (Acariformes: Astigmata) or openings (Parasitiformes: Dermanyssina).

There is some variation in these structures in the two sexes. In slide preparations of females, the primary spermathecal duct is slightly longer, and both the primary and secondary (ovarian) ducts are visible near the base of the bursa copulatrix; in males there are no traces of secondary ducts visible (Fig. 6B). Because these structures in males are unique, it is difficult to employ standard terminology applied in other organisms where both female and male structures appear in the same individual. Monoecy or hermaphroditism are not appropriate, since these terms imply complete female and male systems in the same individual. Similarly, gynandromorphism seems inappropriate because this term typically refers to aberrant individuals where the body is a mosaic of male and female morphologies (e.g. Buczek 1993). The mode of sex determination in the Ascouracaridae is unknown; in fact, the only psoroptidian (Astigmata) family in which it is described is the analgoid family Epidermoptidae Trouessart, 1892, where Promyialges pari (Fain, 1965) has a haplo/diploid karyotype, although true arrhenotoky has not been demonstrated (Helle and Wysoki 1983, Norton et al. 1993). It is possible that the small number of males examined from a single feather may represent an aberration resulting from a local mutation, but further collecting will be needed to test this hypothesis. In the meantime, this unique configuration of the male reproductive system will remain enigmatic.

Acknowledgements. To Fabio A.F. Jacomassa for collecting the feathers from the avian host Megascops choliba; and to Arthur Macarrão for allowing us to use the picture of M. choliba. This study was supported by FAPESP - São Paulo Research Foundation (FAH 2011/50145-0; 2011/20805-8).

\section{REFERENCES}

Atyeo W.T., Gaud J. 1966: The chaetotaxy of sarcoptiform feather mites (Acarina: Analgoidea). J. Kansas Entomol. Soc. 39: 337346.

Buczek A. 1993: Gynandromorphism in ticks. Przegl. Zool. 37: 199-205.

Dabert J., Ehrnsberger R. 1992: Neue Arten bei der Federmilbenfamilie Ascouracaridae Gaud et Atyeo, 1976. Osnabrücker Naturw. Mitt. 18: 109-150.

Dabert J., Ehrnsberger R. 1995: Vassilevascus gen. nov., a new genus of the family Ascouracaridae Gaud et Atyeo, 1976 (Astigmata; Pterolichoidea). Osnabrücker Naturw. Mitt. 20/21: 95-100.

Gaud J., Atyeo W.T. 1976: Ascouracarinae, n. sub-fam. des Syringobiidae, Sarcoptiformes plumicoles. Acarologia 18: 143-162.

Gaud J., Atyeo W.T. 1996. Feather mites of the World (Acarina, Astigmata): the supraspecific taxa. Ann. Mus. R. Afr. Centr. Sci. Zool. 277 (1): 1-187, (2): 1-436.

Gaud J., Kolebinova M. 1973: Ascouracarus vassilevi n. g., n. sp. sarcoptiforme plumicole énigmatique parasite de l'engoulevent d'Europe. Acarologia 15: 349-355.

Gaud J., Atyeo W.T., Klompen H. 1989: Oconnoriidae, a new family of feather mites (Acarina, Pterolichoidea). J. Entomol. Sci. 24: 417-421.

Griffiths D.A., Atyeo W.T., Norton R.A., Lynch C.A. 1990 The idiosomal chaetotaxy of astigmatid mites. J. Zool. 220: 1-32.

Helle W., Wysoki M. 1983: The chromosomes and sex-determination of some actinotrichid taxa (Acari), with special reference to Eriophyidae. Int. J. Acarol. 9: 67-71.

Krantz G.W., Walter D.E. 2009: A Manual of Acarology. Third Edition. Texas Tech University Press, Lubbock, 807 pp.

Mascarenhas C.S., Coimbra M.A.A., Müller G., Brum J.G.W. 2009: Ocorrência de Ornithonyssus bursa (Berlese, 1888) (Acari: Macronyssidae) em filhotes de Megascops choliba (corujinha-do-mato) e Pitangus sulphuratus (bem-te-vi), no Rio Grande do Sul, Brasil. Rev. Bras. Parasitol. 18: 69-70.

Mironov S.V., FAIN A. 2003: New feather mites of the family Ascouracaridae (Astigmata: Pterolichoidea) from some parrots and nightjars. Acarologia 43: 99-111.

NAtress B., Skoracki M. 2009: A new species and further records of quill mites (Acari: Cheyletoidea: Syringophilidae) parasitic on birds (Aves) in England. Zootaxa 2133: 49-54.

Norton R.A., Kethley J.B., Johnston D.E., OConnor B.M. 1993: Phylogenetic perspectives on genetic systems and reproductive modes of mites. In: D. Wrensch and M. Ebbert (Eds.), Evolution and Diversity of Sex Ratio in Insects and Mites. Chapman \& Hall, New York, pp. 8-99.

OConnor B.M. 2009: Cohort Astigmatina. In: G.W. Krantz and D.E. Walter (Eds.), A Manual of Acarology. Third Edition. Texas Tech University Press, Lubbock, pp. 565-657.

Philips J.R., Norton R.A. 1978: Bubophilus ascalaphus gen. et sp. n. (Acarina: Syringophilidae) from the quills of a great horned owl (Bubo virginianus). J. Parasitol. 64: 900-904.

Proctor H.C. 1999. Gallilichus jonesi sp. n. (Acari: Ascouracaridae): a new species of feather mite from the quills of the Australian brush-turkey (Aves: Megapodiidae). Aust. J. Entomol. 38: 77-84.

SkoraCki M., BochKov A.V. 2002: A new quill mite species Bubophilus asiobius sp. n. from the long-eared owl Asio otus (Strigiformes: Strigidae) (Acari: Syringophilidae). Genus 13: 149-152.

D’Souza P.E., Jagannath M.S. 1982: A new genus and species of syringobiid mite (Acari) in the quill of domestic fowl (Gallus domesticus) from South India. Ind. J. Acar. 6: 51-56. 
Valim M.P., Hernandes F.A., Proctor H.C. 2011: Feather mites of Brazil (Acari: Astigmata: Analgoidea and Pterolichoidea). Int. J. Acarol. 37: 293-324.

Walter D.E., Proctor H.C. 2013: Mites: Ecology, Evolution \& Behaviour - Life at a Microscale. Springer, Dordrecht. 486 pp.
Witalinksi W., Szlendak E., Boczek J. 1990: Anatomy and ultrastructure of the reproductive systems of Acarus siro (Acari: Acaridae). Exp. Appl. Acarol. 10: 1-31.

Cite this article as: Hernandes F.A., OConnor B.M. 2015: Cystoidosoma hermaphroditus sp. n., the first representative of the quill mite family Ascouracaridae (Acari: Astigmata: Pterolichoidea) from an owl (Aves: Strigiformes). Folia Parasitol. 62 : 037. 